\title{
Foreign Aid Distorting EfFects: An Empirical Assessment for Sub-Saharan Africa
}

EFECTOS DISTORSIONADORES DE LA AYUDA INTERNACIONAL: UNA EVALUACIÓN EMPÍRICA PARA EL ÁFRICA SUBSAHARIANA

Pacifique Mongongo Dosa

Université Nouveaux Horizons pacifique.mongongodosa@outlook.be

Sergio Tezanos Vázquez University of Cantabria sergiotezanos@unican.es

Nadia Molenaers

University of Antwerp nadia.molenaer@uantwerpen.be

Recibido: julio 2018; aceptado: octubre 2018

\section{ABSTRACT}

Sub-Saharan Africa (SSA) is a key region for the success of the 2030 Agenda for Sustainable Development. However, there is no consensus about the contribution of Official Development Assistance (ODA) in the promotion of economic growth and the reduction of extreme poverty in this region. We therefore build an analytical framework of the distorting effects of foreign aid, and make the subsequent estimations during the period 1991-2014 for SSA. We find four main results: i) ODA to SSA has exerted both distorting and stimulating effects on growth but the latter effects were larger than the former; ii) increasing both aid grants and aid loans, and increasing the ratio of loans to grants, may induce higher growth; iii) however, such a reallocation may only be positive in countries with sustainable debt burdens; and iv) although ODA was effective in aggregate terms, it did not significantly boost the mean income corrected from inequality, which reveals a grave distributional deficiency.

Keywords: Sub-Saharan Africa; poverty eradication; aid effectiveness; Sustainable Development Goals; institutional distortions. 
RESUMEN

La regiōn de África Subsahariana (ASS) es clave para el éxito de la Agenda 2030 para el Desarrollo Sostenible. Sobre la base de las diferencias de las distintas modalidades de ayuda, analizamos el efecto generado por la Ayuda Oficial al Desarrollo (AOD) sobre el ritmo de crecimiento y la reducción de la pobreza en ASS en el periodo 1991-2014. Para ello construimos un modelo analístico sobre los efectos distorsionadores de la ayuda, cuya estimación proporciona cuatro resultados relevantes: i) la ayuda externa ejerce tanto efectos estimulantes como distorsionadores sobre el crecimiento, pero los primeros compensan los segundos; ii) un aumento en ambas modalidades de ayuda y una reasignaciōn entre donaciones y préstamos podría inducir un mayor crecimiento; iii) sin embargo, dicha reasignaciōn sólo sería positiva en paîses con niveles sostenibles de endeudamiento; y iv) aunque la ayuda es eficaz a nivel agregado, no contribuyó significativamente a aumentar el ingreso medio corregido por la desigualdad, lo que revela una grave carencia distributiva.

Palabras clave: África; eficacia de la ayuda; donaciones de ayuda; créditos de ayuda; distorsiones institucionales.

JEL Clasificación: F35. 


\section{INTRODUCTION}

Drawing on the new 2030 Agenda for Sustainable Development, "eradicate extreme poverty for all people everywhere" is the first of the 17 Sustainable Development Goals (SDG). This was solemnly stated by the world's heads of state in the 2015 United Nations (UN) General Assembly's Declaration, Transforming our world:

We resolve, between now and 2030, to end poverty and hunger everywhere; to combat inequalities within and among countries; [...]. We resolve also to create conditions for sustainable, inclusive and sustained economic growth, shared prosperity and decent work for all, taking into account different levels of national development and capacities (UN 2015: 6).

Despite being a promising global commitment to promoting development, is the goal of eradicating poverty realistic and achievable in a 15-year period? Many analysts find that it is not overambitious as it has been previously proven by the Millennium Development Goals (MDG), which successfully contributed to halve the average number of people living in extreme poverty (see, among others, ODI, 2015 and Sachs, 2015). They consequently expect similar development strategies and assistance to accomplish the SDG.

However, given the huge disparities in regional achievements and the differences in poverty levels across developing countries, such a generalisation may be misleading. In particular, one could reasonably wonder whether such a positive forecast is valid for a region such as Sub-Saharan Africa (SSA). The answer from the most "optimistic" analysts is a conditional "yes". They argue that ending poverty in SSA is feasible, provided that developed countries donate more -and more stable- aid (ODI, 2015; UN, 2015). Moreover, a number of investigations have confirmed a fast reduction of poverty and inequality in SSA (Fosu, 2015; Pinkovskiy and Sala-i-Martin, 2014).

Conversely, from a more "pessimistic" viewpoint, other authors argue that foreign aid is not part of the solution but the problem itself. They suggest a "dead aid model" (replacement of Official Development Assistance by marketbased development fundings) which would not distort recipient countries' economic and political environments (Akonor, 2008; Moyo, 2009; Ogundipe et al., 2014). These contradictory viewpoints raise a fundamental question: is aid a way into or a way out of growth and poverty in SSA?

No clear answer comes from the above-mentioned two leading streams of the aid literature, and since they are mutually exclusive, they do not provide 
a single, irrefutable, conclusion. As SSA is the critical region for the goal of eradicating extreme poverty by 2030, and it has also become the main recipient of global ODA since the 1990s, the success of the SDG will clearly depend on the effectiveness of foreign aid in promoting Africa's development. Hence further investigations into the controversy surrounding the effectiveness of aid in SSA are crucial and timely.

Given that the seemingly never-ending controversy surrounding the macroeconomic effectiveness of aid is rooted in the assumption that ODA distorts SSA's economies, we differentiate two aid modalities -aid grants and aid loans- which may impact differently on economic growth. Indeed, aid loans and grants have different financial natures that should be clearly contemplated when assessing the macro-effectiveness of ODA. Furthermore, we distinguish two types of aid impacts: the "overall" impact of aid on growth and the "inequality-adjusted" impact.

With this perspective, this paper has the major goal of assessing the impact of aid and its components on both poverty and the overall economic prosperity. It elaborates on this major goal within two investigation frameworks: firstly, it analyses the relative impacts of aid grants and aid loans on the rate of growth and the inequality-adjusted growth of SSA countries' per capita income during the period 1991-2014. And secondly, it explores the main "distorting effects" that ODA causes on the recipient economies.

The remainder of this paper is structured as follows. Section two reviews the debate on the "aid-growth nexus" in SSA. The third section proposes an analytical model of aid impact on growth, adapted to the peculiarities of the SSA region, and estimated by means of a vector autoregressive (VAR) model. The fourth section presents the main results of the analysis and the last section summarises the conclusions and suggests some economic policies that may increase the effectiveness of aid disbursed to SSA.

\section{The AID EFFECTIVENESS PUZZLE IN SSA}

Between 1995 and 2014, SSA's growth has shown a positive trend with relatively high growth rates, fluctuating between 4 and $8 \%$ (Graphic 1). Apart from year 2009 (due to the financial crisis effect described in Fosu, 2015), that trend was observed along the whole MDGs' era. If SSA keeps growing at this pace, it will double its annual GDP per capita in 9 to 18 years starting with the SDGs' launching year 2015 and, if this growth benefits the poor, SSA will advance towards the goal of eradicating income poverty (Mongongo, 2016). More importantly, it has been recently shown that this remarkable growth is accompanied by significant increases in the income of the poorest citizens (Fosu, 2015; Pinkovskiy and Sala-i-Martin, 2014).

Nevertheless, similar optimistic forecasts about SSA's growth were made in the 1960s, and they were eventually proven to be wrong as the economic performance was poor from 1972 to 1994 (see Graphic 1 and Maddison, 
Graphic 1. Growth dynamics In SSA: $1961-2014$

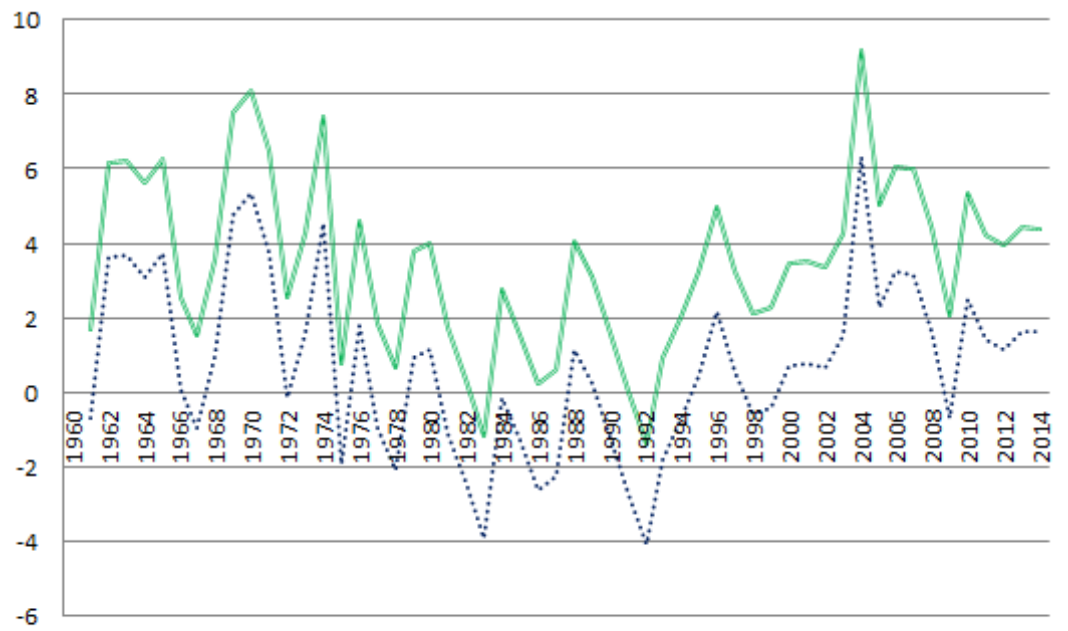

GDP growth (annual \%)

GDP per capita growth (annual \%)

Source: World Bank (2016).

2001). What ensures that the ongoing forecasts in terms of economic growth and poverty reduction are more accurate than those made 50 years ago? To shed light on this question, development researchers have investigated both the causes of the poor performance observed during the "lost development decades" and the key determinants of the current performance. In this context, Collier and Gunning (1999) pointed out the low level of both private and public domestic investments. Given that the average income in SSA was (and is still) below the subsistence level needed to generate savings, some economists saw in foreign aid an alternative to savings in order to boost and maintain the capital accumulation process and the subsequent economic growth (Sachs, 2005a and 2005b). This argument explains why SSA has become the main ODA recipient with an average share of between 40 and $50 \%$ of total disbursements since 1992 (Graphic 2).

Is this positive co-movement since the mid 1990s between "more aid" and "higher economic growth" a simple correlation or an actual causality? Policymakers, aid agencies and some researchers claim that not only ODA causes and sustains the observed growth but also that keeping its delivery would ensure against re-experiencing the "lost development decades" in SSA (Cameron et al., 2013; ODI, 2015; Sachs, 2015; UN 2006, 2015).

Likewise - but in a more nuanced way - Adam and Bevan (2006)'s empirical analysis of the impact of aid inflows on real macroeconomic aggregates, shows 
Graphic 2. Regional oda as a percentage share of total net Disbursements: $1960-2014$
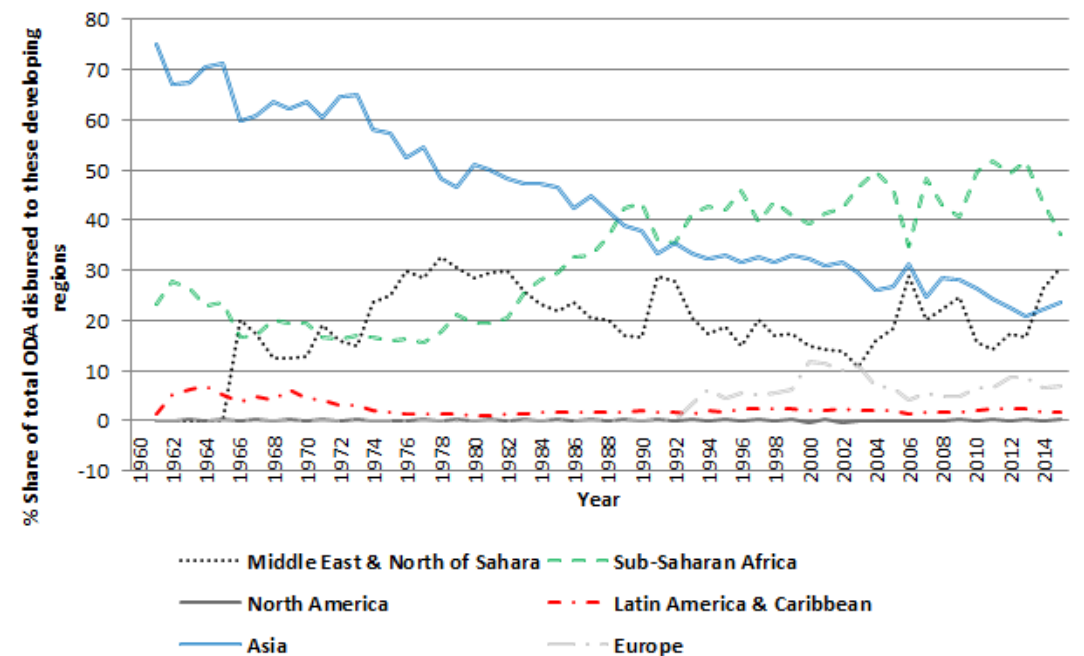

Source: DAC (2016) and World Bank (2016).

that foreign aid allocated in the acquisition of scarce public infrastructures induces higher economic growth provided that those infrastructures increase productivity in the private sector. As a matter of facts, SSA is still largely in need of public infrastructures that would boost private sector productivity. In this sense, Adam and Bevan (2006)'s findings imply that well allocated aid is susceptible to induce growth and reduce poverty in SSA. On the other hand, Adam et al. (2009) investigate the aid macroeconomic impact but from a monetary perspective. They find that foreign aid play an inflation-stabilisation role by aligning domestic deficit financing with the demand for domestic base money, especially by avoiding seigniorage to cover government deficits. This results in higher domestic consumption as it keeps prices low and induces more investments.

All in all, these findings show that aid inflows may have positive outcomes on both nominal and real macroeconomic aspects when they are rightly used. What happens if aid is "wrongly" used? As illustration, they explained the cases of Ethiopia and Ghana, where aid was not productively absorbed (it only increased the monetary reserves to elude the Dutch disease on the exchange rate); and the cases of Tanzania and Uganda, where there were crowding-out fiscal effects due to aid. This issue of negative impacts of aid has been further investigated by researchers grouped within the so-called "aidsceptic development literature". Some findings questioned aid by rejecting the previously-mentioned poverty trap and big push models used by aidoptimistic researchers to advocate for more aid to developing countries. 
Others elaborated on the counter-productive effects of wrongly used aid from an institutional perspective.

Among many others, Kraay and Raddatz (2007) contradict the existence of poverty trap in SSA on the one hand. On the other hand, other development researchers argue that ODA distorts the economic and political institutions that SSA needs to consolidate in order to accelerate the pace of economic growth and (income) poverty reduction (see, for instance, Easterly, 2002 and 2006; Moyo, 2009). Given that most SSA leaders control the economic and the political power, this pessimism meets Angeles et al's (2009) analysis showing that in such a case where elites are more concerned by their own wellbeing than that of the less-well off, the likelihood of misusing aid is very high. Pedersen (2001) spells out such perverse effects - the so-called "institutional distortions" - within the framework of Buchanan's (1975) Samaritan's dilemma. In order to get more aid - he argues-, recipient governments would cut down poverty-reducing efforts as more misery is expected to make donors more altruistic. Similarly, the existence of budget support would undermine the effort of enhancing tax revenues through pro-growth policies. Pedersen (2001) further argues that even if donors accompanied aid with "good policies", inconsistency and credibility problems would not allow them to significantly change the outcome.

As even the most aid-optimistic researchers acknowledge that inadequate policies are as important as the lack of savings in explaining the poor performance of SSA economies (Sachs and Warner, 1997), the overall impact of aid inflows would crucially depend on their effects on the quality of macroeconomic policies and institutions. For instance, if aid disbursed to SSA induces worse macroeconomic policies it is no longer obvious that it would lead to higher economic growth and less poverty. This uncertainty has raised a hot and long debate on the macroeconomic effectiveness of aid in that region.

A number of empirical studies on the macroeconomic impact of aid in SSA have already been conducted. Some found that aid positively impacts on growth (for instance, Houdou, 2010; Fayissa and El-Kaissy, 1999; Juselius et al., 2014; Tombofa et al., 2013) and some found the opposite (Akankor, 2008; Girijasankar, 2008; Hansen and Tarp, 2001; Ogundipe et al., 2014).

An "intermediate" group of studies argues that aid would work (or work better) under sound political and economic environments (for instance, Collier, 2006; Denkabe, 2004; Ekanayake and Chatma, 2010; Kathavate, 2013). Let's exemplify this inconclusive empirical debate by revising four recent studies on the effectiveness of foreign aid in SSA:

On the one hand, Houdou (2010), investigating the long-term effect of foreign direct investments and foreign aid on growth in 36 African countries from 1980 to 2007, found a positive but low impact of aid: a $1 \%$ increase in foreign aid resulted "only" in a $0.05 \%$ increase in growth. In contrast, Girijasankar (2008), in a cointegration analysis of the six poorest and most aid-dependent African countries (Central African Republic, Malawi, Mali, Niger, Sierra Leone and Togo), found that the long-term effect of aid on growth was negative and statistically significant. Nevertheless, Denkabe (2004) reconciled 
these two opposite outcomes by arguing the existence of decreasing marginal returns to aid and thus the existence of a threshold volume (i.e. a turning point) below which aid stimulates growth and above which it undermines growth. In the same vein, Kathavate (2013) spelled out the negative aid-growth elasticity with a quantitative political economy model for SSA; his empirical findings showed that the aid-growth nexus significantly fluctuates with the quality of institutions in which aid operates.

Put together, these four papers show that the issue of whether aid is effective in SSA is not a "yes or no" answer. Aid performance in this region depends on several factors and, given the inconclusiveness of the debate, further investigations are still necessary for a better understanding of whether, when and how foreign aid stimulates economic growth and poverty reduction.

\section{Oda MACROECONOMIC EFFECTIVENESS In SSA: Model SPECIFICATION AND EMPIRICAL} FRAMEWORK

\section{A. Analytical framewOrk}

Despite the fact that ODA is recognised as a heterogeneous development instrument -as is the case in the previously mentioned papers-, it is surprising that most studies on SSA neglect that nature of aid flows. Mavrotas and Nunnenkamp (2007) convincingly argued in favour of considering aid heterogeneity in the assessment of its effectiveness; otherwise, the assessment is more likely to be biased or misunderstood. Hence, some aspects of aid heterogeneity have recently been considered by distinguishing aid types according to either their targets and objectives or their delivery modes. Although this has not yet been done for the case of SSA, this has proved to be useful in giving deeper insights into the effectiveness of aid.

For instance, by considering sectorial allocation, Thiele (2007) revealed that aid was less likely to contribute significantly to the MDG because donors claimed to fund the latter while they were practically funding unrelated sectors. Assessing the effectiveness of aid according to incentives behind modality choices, Jain (2007) questioned donors' prioritisation of projectbased aid while general budget support seemed more efficient, and noticed the willingness of donors to impose their preferences on recipient countries. Furthermore, Mavrotas and Ouattara (2007) distinguished between ODA projects and financial programmes and revealed that the latter induced higher government final consumption while the former increased capital expenditure.

Elsewhere, Tezanos et al. (2013) distinguished between two aid modalities (aid loans and aid grants) in Latin America and the Caribbean (LAC) countries, and concluded that the impact of loans was greater than the impact of grants, a result that - according to the authors - supports the use of both aid modalities in a middle-income region such as LAC, despite its long record of debt unsustainability problems. 
As a matter of fact, these studies have paid little attention to SSA and to date it has not yet been explored the potential of considering the two different aid modalities (aid grants and aid loans) in SSA. Therefore, we have developed an analytical framework accounting for these two aid modalities: aid grants and aid loans. As previously argued by Chang et al. (2002) and Tezanos et al. (2013), such a model disentangling overall ODA in these two components should give deeper insight into the existence of perverse aid effects and the extent to which they undermine the potential of aid to boost and sustain growth.

Hence, following the usual Barro (1991) methodology, we assume that GDP per capita growth $y_{i, t}$ of a country $i$ between years $t_{0}$ and $t_{1}$ is an increasing function of the initial GDP per capita $Y_{i, t 0}$ and a linear combination of explanatory variables $\sum_{k=1}^{n} \beta_{i} X_{i, t}$ :

$y_{i, t}=k_{1}+\delta_{1} Y_{i, t o}+\sum_{k=1}^{n} \beta_{i} X_{i, t}+\mu_{i, t}^{1}$

As we are interested in the specific effects of the two aid modalities, we disentangle $\sum_{k=1}^{n} \beta_{i} X_{i, t}$ in aid grants $(G)$, aid loans $(L)$ and a linear combination of other explanatory variables disregarded in the model $\sum_{k=1}^{m} \Omega_{i} Z_{i, t}$ :

$y_{i, t}=k_{2}+\delta_{2} Y_{i, t 0}+\beta_{G} G_{i, t}+\beta_{L} L_{i, t}+\sum_{k=1}^{m} \Omega_{i} Z_{i, t}+\mu_{i, t}^{2}$

As our second aim is to estimate the effects of these aid modalities on the inequality-adjusted growth, we then shift our focus from the overall income to the mean income corrected from inequality. We use the superscript "ia" to mean inequality adjusted. Drawing on Mongongo (2016), $y_{i, t}$ is corrected from inequality $\left(y_{i, t}^{i a}\right)$ using the complement to one of the Gini coefficients:

$y_{i, t}^{i a}=\left(1-G I N I_{i, t}\right) * y_{i, t}$

As Mongongo (2016) explained, $\left(1-G I N I_{i, t}\right)$ corrects mean income from inequality. Indeed, in the case of perfect inequality, $G I N I_{i, t}$ is 1 and hence $y_{i, t}^{i a}$ is 0 . Consequently $y_{i, t}$ is disregarded in poverty reduction analysis since it fully excludes almost everybody from the economic prosperitv. In the case of perfect equality, $G I N I_{i, t}$ is 0 and hence $y_{i, t}^{i a}$ equals $y_{i, t} \cdot y_{i, t}$ is entirely considered since it is perfectly inclusive and fully cancels out the relative poverty. The remaining cases lie between the two. For instance, at the 
median case where $G I N I_{i, t}$ is $\frac{1}{2}$, half $y_{i, t}$ is taken into account and hence $y_{i, t}^{i a}=\frac{1}{2} y_{i, t}$

It is worth noting that, in case of data availability, we could have the option of correcting income from inequality using detailed decile income distribution as it was done in Tezanos et al. (2013) and Castells-Quintana et al. (2015). While the complement to one of GINI coefficient corrects the mean income from inequality, the decile-based method considers the entire income distribution.

By substituting $y_{i, t}$ with $y_{i, t}^{i a}$ in Equation 2, we have:

$y_{i, t}^{i a}=k_{3}+\delta_{3} Y_{i, t 0}^{i a}+\beta_{G}^{i a} G_{i, t}+\beta_{L}^{i a} L_{i, t}+\sum_{k=1}^{m} \Omega_{i} Z_{i, t}+\mu_{i, t}^{3}$

Equation 4 enables us to assess the impact of aid on mean income corrected from inequality. This is worthwhile since aid is expected to reduce income inequality - especially within the SDG agenda, which aims at poverty eradication and inequality reduction (UN, 2015: 6-7).

All in all, we retain expressions 2 and 4 as our analytical models. They do not assume equal growth impact coefficients of aid grants and aid loans (i.e. $\beta_{\mathrm{G}} \neq \beta_{\mathrm{L}}$ and $\beta_{\mathrm{G}}^{\mathrm{i}} \neq \beta_{\mathrm{L}}^{\mathrm{i} \mathbf{a}}$ ). Indeed, aid loans and grants have very different financial natures. On the one hand, aid loans are refundable and exert a positive incentive to productively invest the resources in order to be able to meet the future repayment obligations, as they cannot be diverted without default risk. This would significantly reduce the perverse effects of aid loans in comparison to those of aid grants.

However, aid loans generate external debt, which may compromise the future financial capacity of recipient countries and hence undermine their overall effectiveness. Specifically, the impact of aid grants will be positive $\left(\beta_{G}, \beta_{G}^{i \mathbf{a}}>0\right)$ if their stimulus on growth compensates for the negative effect on productive incentives. Similarly, the impact of aid loans will be positive $\left(\beta_{\mathrm{L}}, \beta_{\mathrm{L}}^{\mathrm{ia}}>0\right)$ if their stimulus on growth compensates for the debt burden's negative effect. In both cases, productive allocation includes expenditures in social sectors such as in education, health and governance, which indirectly increase production. For instance, education and health do it through positive impacts on labour productivity and good governance via positive impacts on private sector's working environment.

In this setting, we check the following seven disputed hypotheses regarding the effectiveness of aid in SSA:

- Hypotheses of overall aid effectiveness

H1: $\beta_{A}>0$ : Aid as a whole exerts a positive impact on the unadjusted growth (where $\beta_{A}$ combines $\beta_{G}$ and $\beta_{L}$ ).

H2: $\beta_{A}^{i a}>0$ : Aid has a positive impact on the inequality-adjusted growth $\left(\beta_{A}^{I A}\right.$ combines $\beta_{G}^{I A}$ and $\beta_{L}^{I A}$ ). 
- Hypotheses of different impacts of aid grants and loans

$\mathrm{H3}: \beta_{G}>\beta_{L}$ : The impact of aid grants on the overall economic growth is higher than the impact of aid loans.

H4: $\beta_{G}^{i a}>\beta_{L}^{i a}$ : The impact of aid grants on the inequality-adjusted growth is higher than the impact of aid loans.

- Hypotheses of inclusive aid impact

H5: $\beta_{G}^{i a}>\beta_{r}$ : The impact of aid grants is higher on the inequality-adjusted growth than on the overall growth.

H6: $\beta_{L}^{i a}>\beta_{r}$ : The impact of aid loans is higher on the inequality-adjusted growth than on the overall growth.

H7: $\beta_{A}^{i a}>\beta_{A}$ : In aggregated terms, the impact of aid is higher on the inequality-adjusted growth than on the overall growth (where $\beta_{A}^{i a}$ combines $\beta_{G}^{i a}$ and $\beta_{L}^{i a}$ ).

While $\mathrm{H} 1$ and $\mathrm{H} 2$ evaluate the overall aid effectiveness, $\mathrm{H} 3$ and $\mathrm{H} 4$ assess the existence of aid distorting effects. In the case of a lack of institutional distortions, the estimation is expected to confirm these two hypotheses. It is possible to compute the related magnitude with and without inequality adjustment by using the following expressions:

$$
\begin{aligned}
& M_{g, l}=\frac{\beta_{G}-\beta_{L}}{\beta_{L}} \\
& M_{g, l}^{i a}=\frac{\beta_{G}^{i a}-\beta_{L}^{i a}}{\beta_{L}}
\end{aligned}
$$

where $M_{g, l}$ and $M_{g, l}^{a i}$ capture the expected extra effectiveness associated with aid grants considered as the most favourable loan. In line with Sachs (2005a), this would be the adequate "big push" to overcome the poverty trap in SSA. In contrast, if $\mathrm{H3}$ and $\mathrm{H} 4$ are empirically rejected, it will mean that the higher vulnerability of aid grants to political distortions outweighs the above-mentioned advantage. In this case, grants distort economies more than they stimulate them (as claimed by Moyo, 2009). To evaluate the overall effectiveness, $\mathrm{H} 1$ and $\mathrm{H} 2$ merge the effects of aid grants and aid loans with and without inequality adjustment. If empirically confirmed, in aggregated terms the stimulating effects of aid are higher than its distorting effects. Hypotheses $\mathrm{H} 5, \mathrm{H} 6$ and $\mathrm{H} 7$ jointly assess inclusiveness by respectively assuming that the impacts of grants, concessional loans and total aid are higher on the inequalityadjusted economic growth than on the unadjusted economic growth. 


\section{B. IDENTIFICATION PROCEDURE}

Let us recall that in Equations 2 and 4 both $G_{i}, t$ and $L i, t$ are endogenous variables. On the one hand, this is due to the fact that both the eligibility criteria to aid grants and to aid loans and their respective volume partly depend on the income levels of the recipient countries. This would introduce the reversed -or double- causality bias in the estimation. On the other hand, several phenomena - such as armed conflicts, institutional quality and natural resource endowments - affect both economic growth and aid inflows, thereby causing the omitted variable bias. Consequently, we need an appropriate estimation method that enables us to identify the unbiased causal effects of each $\beta$ from Equations 2 and 4 .

Most of the previous empirical studies use lags of endogenous variables as instruments identifying exogenous impacts. ${ }^{1}$ However, the double causality in our model is so obvious and too heavy to be tackled by such weak instruments. This is due to the fact that levels of recipient countries are one of the main eligibility criteria for both aid grant and aid loans. Consequently, the existence of feedback effects is irrefutable and hence modelling them should lead to better estimates. We therefore resort to a VAR model which. It is worth recalling that the estimation of a VAR model does not need control variables. Indeed, in case of existence, a valid VAR regresses itself so good enough that the average effect of unconsidered explanatory variables is null.

Within the VAR framework, the coefficients $\beta G, \beta L, \beta_{G}^{i a}$ and $\beta_{L}^{i a}$ of Equations 2 and 4 are portions of the responses from impulses in the aid equations of two three-series VAR models with GDP per capita without inequality adjustment $y_{t}$ ) and with inequality adjustment $\left(y_{i, t}^{i a}\right)$. This is due to the feedback effects that these models incorporate into the direct impacts captured by the $\beta$ coefficients of isolated equations such as Equations 2 and 4.

Expressions of the two VAR models that we need are derivable from the general expression of the VAR model. A $n$ dimensional VAR process $\overrightarrow{X_{t}}$ can be written as:

$$
\overrightarrow{X_{t}}=C+A_{1} \overrightarrow{X_{t}-1}+\cdots+A_{p} \overrightarrow{X t-p}+\varepsilon t
$$

where $\overrightarrow{X t}$ is a multivariate vector including all the time series considered as part of the VAR model.

We derive Equation 8 corresponding to the VAR process assessing the first and third hypotheses:

1 For instance, Chauvet and Guillaumont (2004), Clemens et al. (2004), Dalgraad et al. (2004), Djankov et al. (2009), Hansen and Tarp (2001), Heady (2008), Rajan and Subramanian (2005), Roodman (2007) and Tezanos et al. (2013) carried out IV estimations within the Arellano-Bond GMM estimator's framework. 
$\overrightarrow{V A R}=\left(\begin{array}{l}Y_{t} \\ G_{t} \\ L_{t}\end{array}\right)=\left(\begin{array}{l}C_{1} \\ C_{2} \\ C_{3}\end{array}\right)+\left(\begin{array}{llll}\phi_{11} & \ldots & \phi_{1 n} & \ldots \\ \phi_{21} & \ldots & \phi_{2 n} & \ldots \\ \phi_{31} & \ldots & \phi_{3 n} & \ldots\end{array}\right)\left(\begin{array}{c}Y_{t-1} \\ \ldots \\ Y_{t-n} \\ G_{t-1} \\ G_{t-n} \\ L_{t-1} \\ \ldots \\ L_{t-n}\end{array}\right)+\left(\begin{array}{c}\varepsilon_{Y, t} \\ \varepsilon_{G, t} \\ \varepsilon_{L, t}\end{array}\right)$

We take into account the inequality adjustment to assesse the second and the fourth hypotheses. This is done by replacing income $\left(\mathrm{y}_{\mathbf{t}}\right)$ by mean income corrected from inequality $\left(\mathbf{y}_{i, t}^{i \mathbf{a}}\right)$ in Equation 8. Besides that, it is worth noting that the assessments of the remaining three hypotheses combine information from these two VAR models.

\section{VARIABLES AND SOURCES}

Table 1 summarises the proxies used for the estimations and Table 2 provides their descriptive statistics. The database includes all of the 51 SSA countries that were listed by the Development Assistance Committee (DAC) of the Organisation for Economic Cooperation and Development (OECD), between 1991 and 2014, as "developing countries" and thus potential ODA recipients.

TABLE 1. VARIABLES' DESCRIPTION AND INFORMATION SOURCES

\begin{tabular}{|l|l|l|}
\hline Variable & Description & Sources \\
\hline GDP & $\begin{array}{l}\text { Annual GDP, constant prices, US \$ } \\
\text { (Year 2005 = 100). }\end{array}$ & $\begin{array}{l}\text { World Bank } \\
(2016)\end{array}$ \\
\hline GDP per capita & $\begin{array}{l}\text { Annual GDP per capita, constant prices, } \\
\text { US \$ (Year 2005 =100). }\end{array}$ & $\begin{array}{l}\text { World Bank } \\
(2016)\end{array}$ \\
\hline GINI coefficient & Average of country indexes & $\begin{array}{l}\text { World Bank } \\
\text { (2016) }\end{array}$ \\
\hline Inequality adjusted GDP & $\begin{array}{l}\text { Annual GDP corrected for inequality, constant } \\
\text { prices, } \\
\text { US \$ (Year 2005=100). }\end{array}$ & $\begin{array}{l}\text { World Bank } \\
(2016)\end{array}$ \\
\hline $\begin{array}{l}\text { Inequality adjusted GDP } \\
\text { per capita }\end{array}$ & $\begin{array}{l}\text { Annual GDP per capita corrected for inequality, } \\
\text { constant prices, US \$ (Year 2005=100). }\end{array}$ & $\begin{array}{l}\text { World Bank } \\
\text { (2016) }\end{array}$ \\
\hline Aid grants & $\begin{array}{l}\text { Percentage of total donors' ODA grants net dis- } \\
\text { bursements over recipients' GDP in each period, } \\
\text { constant prices, US \$ (Year 2013=100). }\end{array}$ & DAC (2016) \\
\hline Aid loans & $\begin{array}{l}\text { Percentage of total donors' ODA loans net dis- } \\
\text { bursements over recipients' GDP in each period, } \\
\text { constant prices, } \\
\text { US \$ (Year 2013=100). }\end{array}$ & DAC (2016) \\
\hline
\end{tabular}


According to the DAC (2016), disbursed grants and loans refer to the actual international transfer of financial resources from donor to recipient countries. They are recorded as net when repaid principals of earlier loans are already deducted from the current gross values.

As grants have no repayment components, their net values are equivalent to their respective gross values. However, the net and gross values are different for concessional loans. As we want to compare the relative effectiveness of these two aid components and their policy implication in SSA, we opt for net loans since they account for the repayment burden. To consider the relative weights, we resort to aid grants and loans as percentage share of the annual GDP. Unlike their absolute values, the relative values in terms of the recipients' GDP give a more realistic insight into the importance of each aid modality in comparison to the size of each recipient's economy. Likewise, we use GDP and inequality-adjusted GDP in per capita terms instead of total values to neutralise the 'population size effects' and hence evaluate the actual impacts on people's income.

TABLE 2. Descriptive Statistics

\begin{tabular}{|l|r|r|r|r|r|}
\hline \multicolumn{1}{|c|}{ Variable } & Obs. & \multicolumn{1}{c|}{ Mean } & Standard deviation & \multicolumn{1}{c|}{ Min. } & \multicolumn{1}{c|}{ Max. } \\
\hline GDP & 24 & $6.413 e+11$ & 189957084070 & $4.239 \mathrm{e}+11$ & $1.007 \mathrm{e}+12$ \\
\hline GDP per capita & 24 & 867.8 & 92.54641 & 768.8 & 1034.0 \\
\hline Gini coefficient & 24 & 0.4502 & 0.03378995 & 0.3773 & 0.5344 \\
\hline Inequality adjusted GDP & 24 & $3.553 \mathrm{e}+11$ & 116107717882 & $1.992 \mathrm{e}+11$ & $5.807 \mathrm{e}+11$ \\
Inequality adjusted GDP per capita & 24 & 478.2 & 67.65428 & 360.7 & 623.6 \\
\hline Aid grants & 24 & 4.654 & 1.76979 & 3.306 & 12.420 \\
\hline Aid loans & 24 & 0.5088 & 1.421734 & -5.8860 & 1.6430 \\
\hline
\end{tabular}

\section{LINEARITY ISSUE}

Such a VAR procedure has a drawback of assuming linear nexuses among the univariate components of the considered auto-regressive multivariate vector. However, this is not that a considerable issue as we have considered aid grants and aid loans in percentages and GDP growth is in percentage by construction. Indeed, this boils down to the usual pre-estimation linearization of most nonlinear models which comes up with estimates in terms of relative and not absolute variations.

\section{E. Pre-estimation diagnostics}

As VAR models are made for stationary processes, we first need to carry out a stationarity analysis on the variables in order to select and estimate 
the valid VAR models, including their respective stationary forms ${ }^{2}$. On the one hand, the plots, the auto- and partial correlation functions together with the Dickey-Fuller unit root tests prove that GDP and inequality-adjusted GDP are stationary after being log-differenced once. Such a transformation is quite interesting since it leads to their respective growth rates.

On the other hand, grants and loans are stationary without any additional transformation. As we have considered their respective percentage share of GDP, they are also expressed in percentage as GDP growth itself. Consequently, our estimates will be interpreted as elasticities (the percentage change in economic growth induced by one percentage change in grants or loans). With regard to the model selection, we select the appropriate order, minimising the Akaike information criterion (AIC), Schwarz's Bayesian information criterion (SBIC or SC), the Hannan-Quinn information criterion (HO) and Akaike's Final Prediction Error criterion (FPE).

TABle 3. Valid VAR selection parameters

\begin{tabular}{|r|r|r|r|}
\hline \multicolumn{1}{|c|}{ Criteria } & VAR (1) & VAR (2) & \multicolumn{1}{|c|}{ VAR (3) } \\
\hline AIC(n) & 0.7706621 & 0.1472333 & -0.26292832 \\
\hline $\mathrm{HQ}(\mathrm{n})$ & 0.8716115 & 0.3238948 & -0.01055474 \\
\hline $\mathrm{SC}(\mathrm{n})$ & 1.3671499 & 1.1910869 & 1.22829112 \\
\hline $\mathrm{FPE}(\mathrm{n})$ & 2.2030356 & 1.2921101 & 1.09350781 \\
\hline
\end{tabular}

For the unlimited maximal lag, the FPE suggests VAR (3) while the rest suggest VAR (4). As in this case both VAR (3) and VAR (4) are expected to be valid, we select VAR (3) in order to gain one additional degree of freedom. Table 3 provides values of these information criteria for a maximal lag of 3.

As shown in Table 3, FPE, AIC and SBIC criteria strongly prefer VAR (3) to both VAR (1) and VAR (2). The SC criterion strongly rejects VAR (1) and slightly prefers VAR (2) to VAR (3). As for the SC criterion, the difference in the minimal values for VAR (2) and VAR (3) is negligible and the other selection criteria strongly suggest VAR (3). We therefore choose VAR (3) as the most appropriate to the statistical structure of our data set. Nonetheless, the statistical validity of the estimates of this model lies in the assumption that the residuals from the estimation are drawn from a multivariate white noise error term. This means that, on average, its univariate components should be zero $\left(E\left(\overrightarrow{\varepsilon_{t}}\right)=0\right)$. the correlations among them should not exist either at lead or at lag $\left(\operatorname{cov}\left(\overrightarrow{\varepsilon_{t}}, \overrightarrow{\varepsilon_{t-k}}\right)=0 \forall k>0\right)$, and that the covariances should be

\footnotetext{
${ }^{2}$ Even though they may deviate for a little while, stationary processes fluctuate around their means (or trends) over time. In the case of deviation, they will definitely revert back to the latter. Therefore, resorting to the stationary forms of GDP, aid grant and aid loans ensures that our estimations do not merely provide spurious relationships driven by time, which would simultaneously cause changes in all of them in the case of non-stationarity.
} 
constant $\left(\operatorname{cov}\left(\overrightarrow{\varepsilon_{t}}\right)=\Sigma\right)$. Graphic 2 and Tables 4 and 5 provide the outputs of our tests of this set of assumptions.

Graphic 3. Dependency structure of the residuals from of the Retained VAR (3)

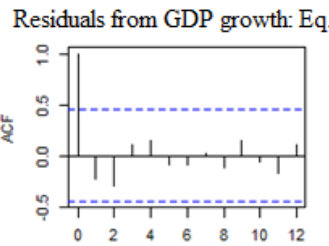

Lag

Cross-correlation between 1 and 2

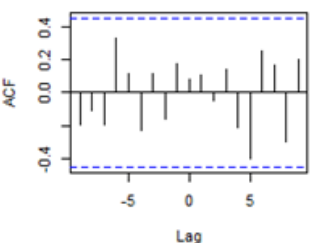

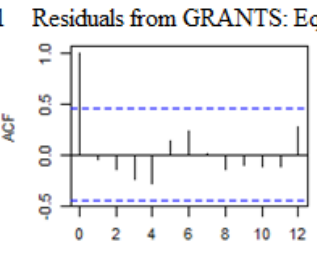

Lag

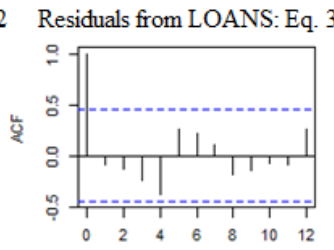

Lag
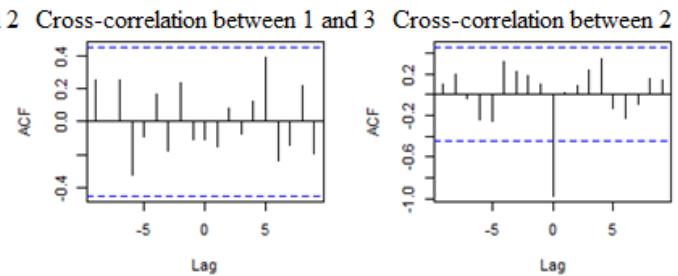

Indeed, both the auto and partial correlation functions depicted in Graphic 2 confirm that the residuals from the selected VAR (3) are uncorrelated both in lead and in lag ( $\left.\operatorname{cov}\left(\overrightarrow{\varepsilon_{t}}, \overrightarrow{\varepsilon_{t-k}}\right)=0 \forall \mathrm{k}>0\right)$ ). Furthermore, as summarised in Table 4 , they all have zero means $\left(E\left(\overrightarrow{\varepsilon_{t}}\right)=0\right)$.

In addition, Table 4 shows that both the lower and the upper limits of the ranges of these univariate residuals are relatively close and their respective medians are close to zero. As they summarise variables disregarded in the model, this assures us that the latter have not biased our estimates. Table 5 reinforces this result by showing that the three univariate components of the multivariate residual have constant variances.

Table 4. Descriptive statistics of Residuals of the estimated VAR (3)

\begin{tabular}{|l|r|r|r|}
\hline $\begin{array}{c}\text { Res. } \\
\text { Stat. }\end{array}$ & From GDP growth eq. 1 $\left(\boldsymbol{\varepsilon}_{\boldsymbol{Y}, \boldsymbol{t}}\right)$ & From GRANTS eq. 2 $\left(\boldsymbol{\varepsilon}_{\boldsymbol{G}, \boldsymbol{t}}\right)$ & From LOANS eq. 3 $\left(\boldsymbol{\varepsilon}_{\boldsymbol{L}, \boldsymbol{t}}\right)$ \\
\hline Min. & -1.24942 & -1.5664 & -2.3084 \\
\hline $1^{\text {st }}$. Qu. & -0.50148 & -0.8573 & -0.3989 \\
\hline Median & 0.03491 & -0.2039 & 0.1620 \\
\hline Mean & 0.00000 & 0.0000 & 0.0000 \\
\hline $3^{\text {rd. }}$ Qu. & 0.45376 & 0.4304 & 0.6805 \\
\hline Max. & 1.66794 & 2.9834 & 1.2354 \\
\hline
\end{tabular}


Table 5. Covariance and correlation matrixes of the selected VAR (3)

\begin{tabular}{|c|r|r|r|}
\hline Covariance & \multicolumn{1}{|c|}{$\varepsilon_{Y, t}$} & $\varepsilon_{G, t}$ & $\varepsilon_{L, t}$ \\
\hline$\varepsilon_{Y, t}$ & 1.2047 & 0.1508 & -0.1493 \\
\hline$\varepsilon_{G, t}$ & 0.1508 & 2.7665 & -2.0647 \\
\hline$\varepsilon_{L, t}$ & -0.1493 & -2.0647 & 1.6350 \\
\hline Correlation & $\varepsilon_{Y, t}$ & $\varepsilon_{G, t}$ & $\varepsilon_{L, t}$ \\
\hline$\varepsilon_{Y, t}$ & 1.00000 & 0.08262 & -0.1064 \\
\hline$\varepsilon_{G, t}$ & 0.08262 & 1.0000 & -0.9708 \\
\hline$\varepsilon_{L, t}$ & -0.10642 & -0.97082 & 1.0000 \\
\hline
\end{tabular}

As already observable at lag zero of the cross-correlation function between aid grants and aid loans in Graphic 2, the contemporaneous correlation between the residuals from their respective equations is large and statistically significant. As VAR models do not assume zero contemporaneous correlations among residuals but only zero cross-correlations in lead and in lag, this does not question the validity of the selected model.

All in all, the pre-estimation diagnostics confirms that this multivariate residual is a sample of a white noise process and consequently confirms the validity of the retained VAR (3) model.

\section{MAIN RESULTS}

According to our estimations (Table 6), a $1 \%$ increase in aid grants has raised SSA growth rate by around 2.46 percentage points, and an equivalent increase in aid loans has had a greater impact on growth (with an average coefficient of 3.05). These results suggest that, on the one hand, the positive impact of aid loans compensates for the inconvenient repayment burdens attached to them. On the other hand, although aid grants are relatively less effective than aid loans in promoting growth, they still exert a positive and significant impact.

It is worth recalling that net aid loans disbursed to SSA are relatively low in comparison with aid grants (they represent $0.51 \%$ and $4.65 \%$ of GDP, respectively). However, according to our estimations, loans exert a relatively higher effect on growth than grants (roughly 0.6 percentage points of extra 
Table 6. Direct effects of GRants and of Loans on eConomic Growth

\begin{tabular}{|c|c|c|c|c|c|c|c|c|c|}
\hline & Lag 1 & Std. Error & P-Value & Lag 2 & Std. Error & P-Value & Lag 3 & Std. Error & P-value \\
\hline Aid grants (1) & 2.45982 & 0.75452 & 0.00984 & -1.05074 & 1.30316 & 0.44085 & -1.13834 & 0.92391 & 0.24913 \\
\hline Aid loans (2) & 3.04601 & 0.86623 & 0.00655 & -0.96044 & 1.58779 & 0.56019 & -1.31964 & 1.05220 & 0.24137 \\
\hline$(2)-(1)$ & 0.5862 & 0.23953 & 0.01830 & 0.09030 & 0.98036 & 0.67040 & -0.18130 & 0.29197 & 0.77170 \\
\hline
\end{tabular}

effect). It is worth noting that this 0.6 difference is statistically significant and economically considerable. Consequently, this suggests that a reallocation of ODA from grants to loans would stimulate higher economic performance. Obviously, this reallocation is only promising for those countries with sustainable debts.

Apart from these direct effects, both grants and loans may be affected by feedback effects from growth on them, or by their mutual interactions. The first part of Table 7 shows that an increase in economic growth does not affect either aid grants or aid loans. However, one would expect the opposite as lower levels of GDP per capita strengthen the eligibility of getting both grants and concessional loans. This is not the case because the level of SSA per capita GDP is still relatively low (in comparison with other developing regions) to consider that its growth rate is a sign that the region has become developed enough to handle its growth path with less - or no- foreign assistance.

TABLE 7. GDP gROWTH FEEDBACK EFFECTS AND GRANTS-LOANS INTERACTIONS

\begin{tabular}{|c|c|c|c|c|c|c|}
\hline \multicolumn{7}{|c|}{ 1. Feedback effect of $1 \%$ of increase of GDP growth on both grants and on loans } \\
\hline & Lag 1 & P-Value & Lag 2 & P-Value & Lag 3 & P-value \\
\hline Aid grants & 0.008206 & 0.985 & 0.162785 & 0.634 & 0.554216 & 0.184 \\
\hline Aid loans & -0.17311 & 0.617 & 0.01438 & 0.956 & -0.51200 & 0.118 \\
\hline \multicolumn{7}{|c|}{ 2. Direct effects of $1 \%$ of increase of aid loans on aid grants } \\
\hline & Lag 1 & P-Value & Lag 2 & P-Value & Lag 3 & P-value \\
\hline Aid loans & 2.630868 & 0.076 & -1.561343 & 0.533 & 0.698197 & 0.672 \\
\hline \multicolumn{7}{|c|}{ 3. Direct effects of $1 \%$ of increase of aid grants on aid loans } \\
\hline & Lag 1 & P-Value & Lag 2 & P-Value & Lag 3 & P-value \\
\hline Aid grants & -0.80268 & 0.385 & 1.11574 & 0.481 & -0.62921 & 0.573 \\
\hline
\end{tabular}

Moreover, the second part of Table 7 shows that an increase in aid loans has a positive and significant impact on aid grants, whereas the third part of the table shows that an increase in aid grants does not have a significant impact on aid loans. This suggests that the previously mentioned efficiency 
gain from the loans-to-grants reallocation would never lead to an extreme situation where all donors give all ODA in the form of loans. In fact, grants serve some donors' priorities that loans cannot serve and hence they would never completely replace the former modality. That is the case with ODA funding the fight against terrorism or underpinning policies controlling migration from recipient countries. It is also the case with ODA funding projects that promote donors' values, interests and convictions such as democracy and human rights. On the one hand, recipient countries would have no - or very little- incentive to negotiate or to accept ODA in the form of loans in these cases. On the other hand, grants also allow donors to get a relatively higher control of such sensitive targets and make recipient countries more accountable to them.

Graphic 3 depicts the overall impacts accounting for all the feedback and interaction effects -including effects that are too small to be statistically considered and hence were disregarded in the previous discussion. Exploring this Graphic from right to left, the first Figure depicts the overall percentage change in GDP growth and aid grants induced by a temporary $1 \%$ increase in aid loans. As already quantified in Table 6, such an impulse causes an increase in GDP growth, but it also increases the level of aid grants. Both GDP growth and aid grants keep growing until the impulse is off (i.e. when 'aid loans' touches the horizontal axis).

Graphic 4. Overall impacts: Direct, feedback and interaction efFects
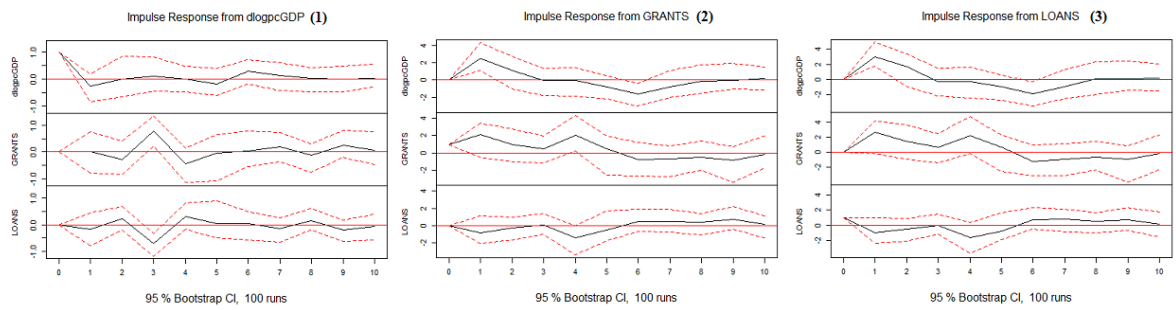

This matches our previous results suggesting that aid loans have a positive impact on growth and that aid grants complement aid loans to fund specific interests that the latter cannot adequately fund. The second Figure shows the overall percentage change in GDP growth and aid loans caused by a temporary $1 \%$ increase in aid grants. As already quantified in Table 6, economic growth is increased by such an impulse. Subsequently, Figure 3 confirms that aid grants exert a positive impact on growth.

Furthermore, although we previously explained that aid grants do not affect aid loans, the second Figure shows that an increase in aid grants decreases aid loans. This is not a contradiction but another way of presenting the same fact. Indeed, drawing on Table 7 (part 3), a $1 \%$ increase in aid grants induces a $0.8 \%$ decrease in aid loans. The p-value $(0.385)$ suggests that this $0.8 \%$ impact is 
not significantly different from zero and hence it has been disregarded in our previous explanation. However, the impulse-response function still visualises such a negligible effect to give an insight into the global interactions within the estimated VAR model. Unlike aid grants - which are a strategy complemented by aid loans - this suggests that loans may be substituted by grants. In other words, donors may partly replace aid loans with aid grants without jeopardising their strategic objectives. However, in addition to the foregone repayments, the previous results suggest an efficiency loss in such a reallocation. Consequently, it should only be done when necessary. Countries with unsustainable debt burdens would logically benefit from such an exceptional reallocation of ODA.

Figure 1 of Graphic 3 visualises the small feedback effects of economic growth on both grants and loans. Although statistically insignificant, they predict that foreign aid should never be considered a never-ending funding source for the development of SSA. Indeed, they suggest that the more donors assess SSA's GDP as relatively high, the fewer grants and concessional loans they will provide. Therefore, as SSA economies are growing relatively fast, policymakers should already start thinking about alternative sources to sustain the financing of the ongoing development process. Obviously, one of the available options is resorting to market funds.

Beyond these impacts of both grants and concessional loans on SSA economic growth, what has been the effect on the "inequality-adjusted" growth rate? In order to test this, we estimate a similar VAR model and carry out the same analysis using the inequality-adjusted GDP per capita growth rate. The estimation offers a worrisome result: neither concessional loans nor grants have statistically significant impacts on the inequality-adjusted growth (Table 8, Part 1), and the latter has no significant effects on either aid grants (Table 8, Part 2) or aid loans (Table 8, Part 3).

In comparison to the positive and strongly significant effects for the case without inequality adjustment, this suggests that aid in SSA is not targeting the poorest citizens well -and/or it is used in a way that its effects on the poorest citizens can only be observable over a much longer period of time.

Moreover -as happened in the benchmark case without inequality adjustment-, Part 4 of Table 8 still confirms that an increase in aid loans induces a significant increase in aid grants. Similarly, Part 5 of Table 8 again confirms that an increase in aid grants does not induce an increase in aid loans. Finally, it is worth noting that the positive and significant effect of an increase in aid loans on aid grants implies neither a direct nor an indirect positive effect of aid loans and grants on the inequality-adjusted growth, not only because neither of these two aid modalities have a significant impact on the inequalityadjusted growth but also because the latter has no significant feedback effects on either modality.

This result - aid and its component do not significantly stimulate mean income corrected from inequality - is consist with recent empirical papers on the aid macroeconomic ineffectiveness such as that of chong et al. (2009) finding that aid has no significant impact on poverty and inequality and that of 
TABLE 8. INTERACTIONS BETWEEN GDP GROWTH ADJUSTED FOR INEQUALITY, AID GRANTS AND AID LOANS

\begin{tabular}{|c|c|c|c|c|c|c|}
\hline \multicolumn{7}{|c|}{ 1. Direct effects of $1 \%$ of increase of aid loans and aid grants on inequality adjusted growth } \\
\hline & Lag 1 & P-Value & Lag 2 & P-Value & Lag 3 & P-value \\
\hline Aid grants & 3.3160 & 0.4377 & 2.4655 & 0.7122 & -3.0835 & 0.4676 \\
\hline Aid loans & 3.7477 & 0.4558 & 2.4655 & 0.7122 & -3.1991 & 0.5341 \\
\hline \multicolumn{7}{|c|}{ 2. Direct effect of $1 \%$ of increase of inequality adjusted GDP growth on aid grants } \\
\hline & Lag 1 & P-Value & Lag 2 & P-Value & Lag 3 & P-value \\
\hline Aid grants & 0.07756 & 0.5109 & 0.07987 & 0.3250 & 0.07186 & 0.3593 \\
\hline \multicolumn{7}{|c|}{ 3. Direct effect of $1 \%$ of increase of inequality adjusted GDP growth on aid loans } \\
\hline & Lag 1 & P-Value & Lag 2 & P-Value & Lag 3 & P-value \\
\hline Aid loans & -0.04860 & 0.6113 & -0.07640 & 0.2527 & -0.06541 & 0.3086 \\
\hline \multicolumn{7}{|c|}{ 4. Direct effects of $1 \%$ of increase of aid loans on aid grants } \\
\hline & Lag 1 & P-Value & Lag 2 & P-Value & Lag 3 & P-value \\
\hline Aid loans & 3.59512 & 0.0411 & -3.98019 & 0.1378 & 1.39057 & 0.3939 \\
\hline \multicolumn{7}{|c|}{ 5. Direct effects of a $1 \%$ of increase of aid grants on aid loans } \\
\hline & Lag 1 & P-Value & Lag 2 & P-Value & Lag 3 & P-value \\
\hline Aid grants & -1.91754 & 0.0995 & 2.52522 & 0.1616 & -0.97783 & 0.3716 \\
\hline
\end{tabular}

Bourguignon et al. (2009) finding that aid has a very small significant impact on poverty and inequality merely for the lowest deciles of the income distribution. This implies that on average it has no significant impact as shown in our VAR model regressed on the mean income corrected from inequality.

\section{CONCLUSIONS}

The new 2030 Agenda for Sustainable Development pledges to eradicate poverty in 15 years and, once again - as previously happened with the MDGs, most of the attention is on SSA, as this is the region with the highest extreme poverty rates, but it is also the main global recipient of foreign assistance. Given that the average income in this region is too low to generate savings and to sustain the necessary level of economic growth to achieve the SDG, a good functioning of ODA is crucial to make sure that SSA will not be left behind. Therefore, shedding light on the seemingly never-ending controversy about the effectiveness of aid in this African region is especially timely.

Previous studies on the macroeconomic effectiveness of foreign aid have paid very little attention to the assessment of the existence of aid-growth distorting effects in SSA. Therefore, this paper investigates aid effectiveness from two 
research perspectives: firstly, analyses the relative impacts of aid grants and aid loans on the rate of growth of SSA countries' per capita income and on the per capita mean income corrected from inequality during the period 1991-2014; and secondly, explores the main distorting effects that ODA causes on the recipient economies. Recognising the heterogeneous nature of ODA flows, we examine the relative effects of aid grants and aid loans on economic growth and discuss the strengths and weaknesses of these two aid modalities. The lack of repayment burden on poor countries has been considered the major strength of aid grants but it has also been associated with higher risks of investing such concessional resources into unproductive activities. Conversely, aid loans are generally considered to exert positive incentives to productively invest the resources in order to be able to meet the future repayment obligations, but they also generate a debt burden that may be unsustainable for some poor countries. Therefore, we assumed for the estimations that the net impact of each aid modality is positive if its strengths compensate for its weaknesses.

Given that both aid grants and aid loans not only affect economic growth but are also impacted by the latter within a kind of 'loop of causality', we use VAR models in order to incorporate such interdependencies and control the effects of other omitted processes that would otherwise bias the estimation results. The econometric estimation points out four relevant results in relation to the aggregate impact of ODA in SSA:

Firstly, although foreign aid exerted both distorting and stimulating effects on SSA's economic growth, its overall net result was significantly positive. This positive net impact underpins the optimistic aid stream (Fayissa and El-Kaissy, 1999; Juselius et al., 2014; Sachs, 2015; Tombofa et al., 2013, and others) against the aid sceptics (such as Akankor, 2008; Moyo, 2009; Ogundipe et al., 2014). However, it also confirms the concerns raised by the latter about the existence of aid distorting effects - even though they are assessed to be lower than expected.

Secondly, while both aid components have positive and significant impacts on economic growth, aid loans are relatively more effective than aid grants. Subsequently, both an increase of each of these two aid modalities and a reallocation from aid grant to aid loans for a given amount of ODA are expected to induce higher growth.

Thirdly, a reallocation from aid grants to aid loans would provide an adequate incentive to use aid resources in a more productive way, but its complete implementation $-100 \%$ loans versus $0 \%$ grants - is not practical as some strategic targets of ODA are incompatible with aid loans. Nonetheless, donors still have relatively wide room for manoeuvre since ODA to SSA is largely delivered in terms of grants. Moreover, the success of such reallocation assumes that the debt burden of the recipient country is sustainable; otherwise, the opposite reallocation - from aid loans to aid grants - would be preferable.

Fourthly, foreign aid does not significantly impact mean income corrected from inequality. This is an alarming result as ODA is officially intended to reduce poverty and inequality - especially if it is intended to underpin the 
SDG target of poverty eradication and inequality reduction. This result -aid and its component do not significantly stimulate mean income corrected from inequality - is consist with recent empirical papers on the aid macroeconomic ineffectiveness such as that of Chong et al. (2009), finding that aid has no significant impact on poverty and inequality; and that of Bourguignon et al. (2009), finding that aid has a very small significant impact on poverty and inequality merely for the lowest deciles of the income distribution. This implies that, on average, aid has no significant impact as shown in our VAR model regressed on the mean income corrected from inequality.

In sum, our findings support both the increase in ODA resources to SSA in the SDG era and the use of both aid grants and loans in this - mainly - lowincome region. Furthermore, we cannot infer that concessional loans are totally preferable to grants; on the contrary, grants should still be concentrated in those African countries with lower repayment capacity and more restricted access to credit. But the use of concessional loans should be increased in those economies that need resources for financing productive activities, offer guaranties of repayment and are more affected by institutional distortions. Therefore, this piece of research opens the door for future analysis on the socioeconomic, political and institutional conditions that are more appropriate for the - effective- use of aid loans and grants.

Finally, even though we made all the necessary tests to make sure the estimated VAR model is valid, we welcome further investigations including other robustness checks in line with our findings. Among many other options, one could consider extending the investigation to different regions and time periods.

\section{REFERENCES}

Adam, C.S., Bevan, D. (2006): "Aid and the Supply Side: Public Investment, Export Performance, and Dutch Disease in Low-Income Countries", World Bank Economic Review, 20(2), 261-290.

Adam, C.S., O'Connell, E., Buffie, F. and Patillo, C. (2009): "Monetary Policy Rules for Managing Aid Surges in Africa", World Bank Economic Review, 20(2), 261-290.

Akonor, K. (2008): "Foreign Aid to Africa: A Hallow Hope?", International law and politics, 40, 1071-1078.

Angeles, L. and Neanidis, K. C. (2009): "Aid Effectiveness: The Role of the Local Elite”, Journal of Development Economics, 90(1),120-134.

Barro, R. (1991): "Economic Growth in a Cross Section of Countries", The Quarterly Journal of Economics, 106(2), 407-443.

Bourguignon, F., Levin, V and Rosenblatt, D. (2009): "International Redistribution of Income", World Development, 37(1), 1-10.

Buchanan, J.M. (1975): "The Samaritan's Dilemma”, In: Phelps, E. (Ed.), Altruism, Morality, and Economic Theory. Russell Sage Foundation, New York, pp. $71-85$. 
Cameron, D., Sirleaf, E. J. and Yudhoyono, S. B. (2013): A New Global Partnership: Eradicate Poverty and Transform Economies through Sustainable Development: The Report of the High-Level Panel of Eminent Persons on the Post-2015 Development Agenda, UN Secretariat.

Catells-Quintana D. and Larrú, J.M. (2015): "Does Aid Reduce Inequality? Evidence for Latin America", European Journal of Development Research, 27(5), 826-849.

Chang, C.C., Fernandez, A. and Servén, L. (2002): "Measuring Aid Flow: A New Approach", Global Economy Quarterly, 3(2), 197-218.

Chauvet, L. and Guillaumont, P. (2004): "Aid and Growth Revisited: Policy, Economic Vulnerability and Political Instability”, in Tingodden, B., Stern, N., Kolstad, I. (Eds.): Towards Pro-Poor Policies: Aid, Institutions and Globalization, Oxford University Press, Washington DC, pp. 95-109.

Chong, A., Calderon, C. and Gradstein, M. (2009): "Can Foreign Aid Reduce Income Inequality and Poverty?", Public Choice, $140(1-2), 59-84$.

Collier, P. (2006): "African Growth: Why a Big Push?", Journal of African Economies, 15(2), 188-211.

Collier, P. and Gunning, J.W. (1999): "Why Has Africa Grown Slowly?”, Journal of Economic Perspectives, 13(3), 3-22.

Denkabe, P. (2004): "Policy, Aid and Growth: A Threshold Hypothesis", Journal of African Development, 1 (1), 39-45.

Development Assistance Committee (2016): "International Development Statistics (IDS)”, online database, OECD: http://www.oecd.org/dac/stats/ idsonline.htm (accessed for the last time on July 29, 2016).

Djankov, S., Montalvo, J.G. and Reynal-Querol, M. (2009): "Aid with Multiple Personalities", Journal of Comparative Economics, 37(2), 217-229.

Easterly W (2008): Hayekian insights on development, Cato Policy Report, Cato Institute's online publication, http://www.cato.org/policy-report/ mayjune-2008/hayekian-insights-development (accessed for the last time on July 29, 2016).

Easterly, W. (2002): The Elusive Quest for Growth: Economists'Adventures and Misadventures in the Tropics, The MIT Press, Cambridge.

Easterly, W. (2006): The White Man's Burden: Why the West's Efforts to Aid the Rest Have Done So Much III and So Little Good, Penguin press.

Ekanayake, E.M. and Chatma, D. (2010): "The Effect of Foreign Aid on Economic Growth in Developing Countries", Journal of International Business and Cultural Studies, 3, 1-13.

Fayissa, B. and El-Kaissy, M.I. (1999): "Foreign Aid and the Economic Growth of Developing Countries (LDCs): Further Evidence", Studies in Comparative International Development, 34(3), 37-50.

Fosu, K.A. (2015): "Growth, Inequality and Poverty in Sub-Saharan Africa: Recent Progress in a Global Context", Oxford Development Studies, 43(1), 44-59.

Girijasankar, M. (2008): "Foreign Aid and Economic Growth: A Cointegration Analysis of the Six Poorest African Countries", Economic Analysis and Policy, 38(2), 251-260. 
Hansen, H. and Tarp, F. (2001): "Aid and Growth Regressions", Journal of Development Economics, 64(2): 547-570.

Hansen, H. and Tarp, F. (2000): "Aid Effectiveness Disputed", Journal of International Development, 12(3), 375-398.

Houdou, N. (2010): "Foreign Aid, Foreign Direct Investment and Economic Growth in Sub-Saharan Africa: Evidence from Pooled Mean Group Estimator (pmg)", International Journal of Economics and Finance, 2(3), 39-45.

Jain, S. (2007): "Project Assistance Versus Budget Support: An IncentiveTheoretic Analysis of Aid Conditionality", Review of World Economics/ Weltwirtschaftliches Archiv, 143 (4), 694-719.

Juselius, K., Møller, N.F. and Tarp, F. (2014): "The Long-Run Impact of Foreign Aid in 36 African Countries: Insights from Multivariate Time Series Analysis", Oxford Bulletin of Economics and Statistics, 76(2), 153-184.

Kathavate, J. (2013): "Direct Indirect Effects of Aid Volatility on Growth: Do Stronger Institutions Play a Role?", Munich Personal RePEC Archive, No. 45187, online at http://mpra.ub.uni-muenchen.de/45187/ (accessed for the last time on July 29, 2016).

Kraay, A. and Raddatz, C. (2007): "Poverty Traps, Aid, and Growth", Journal of Development Economics, 82(2): 315-347.

Maddison, A. (2001): The World Economy: A Millennial Perspective, Development Centre Studies. OECD, Paris.

Mavrotas, G. and Nunnenkamp, P. (2007): "Foreign aid Heterogeneity: Issues and Agenda", Review of World Economics / Weltwirtschaftliches Archiv, 143(4), 585-595.

Mavrotas, G. and Ouattara, B. (2007): "Aid Modalities and Budgetary Response: Panel Data Evidence", Review of World Economics/Weltwirtschaftliches Archiv, 143(4), 720-741.

Mongongo, P.D. (2016): "On the Measurement and Use of Equality Weighted Growth", Iberoamerican Journal of Development Studies, 5(2), 126-139.

Moyo, D. (2009): Dead Aid: Why Aid is Not Working and How There is Another Way for Africa, Penguin, London.

Ogundipe, A., Ojeaga, P. and Ogundipe, M.O. (2014): “Is Aid Really Dead? Evidence from Sub-Saharan Africa”, International Journal of Humanities and Social Sciences, 4, 10(1), 300-314.

Overseas Development Institute (2015): Combining Finances and Policies to Implement a Transformative Post-2015 Development Agenda. European Report on Development 2015, European Commission's online publication, http://ecdpm.org/wp-content/uploads/2015-European-Report-onDevelopment-English.pdf (accessed for the last time on July 29, 2016).

Pedersen, K.L. (2001): “The Samaritan's Dilemma and the Effectiveness of Development Aid", International Tax and Public Finance, 8(5), 693-703.

Pinkovskiy, M. and Sala-i-Martin, X. (2014): "Africa is on Time", Journal of Economic Growth, 19(3), 311-338.

Sachs, J. (2005a): The End of Poverty: Economic Possibilities for Our Time, Penguin, London. 
Sachs, J. (2005b): Investing in Development: A Practical Plan to Achieve the UN Millennium Development Goals, UN Millennium Project's online publication, http://www.unmillenniumproject.org/documents/MainReportCompletelowres.pdf (accessed for the last time on July 29, 2016).

Sachs, J. (2015): The Age of Sustainable Development, Columbia University press, New York.

Sachs, J. and Warner, A.M. (1997): "Sources of Slow Growth in Sub-Saharan Economies", Journal of African Economies, 6(3), 335-76.

Solow, R. (2007): "The Last 50 Years in Growth Theory and the Next 10", Oxford Review of Economic Policy, 23(1), 3-14

Tezanos, S., Quiñones, A. and Guijarro, M. (2013), "Inequality, Aid and Growth: Macroeconomic Impact of Aid Grants and Loans in Latin America and the Caribbean", Journal of Applied Economics, 16(1), 153-177.

Thiele, R., Nunnenkamp, P., Dreher, A. (2007): "Do Donors Target Aid in Line with the Millennium Development Goals? A Sector Perspective of Aid Allocation", Review of World Economics/Weltwirtschaftliches Archiv, 143(4): 596-630.

Tombofa, S.S., Edoumiekumo, G.S. and Obudah, C.B. (2013): "Foreign Aid, Debt and Growth Nexus in Nigeria", Research Journal of Economics, Business and ICT, 8(2), 18-24.

United Nations (2006): Economic Development in Africa-Doubling aid: Making the "Big Push" Work, Geneva UN's online publication, http://unctad.org/ en/Docs/gdsafrica20061_en.pdf, (accessed for the last time on July 29, 2016).

United Nations (2015): Transforming Our World: the 2030 Agenda for Sustainable Development, A/RES/70/1.

World Bank (2016): World Development Indicators' Online Database, http:// data.worldbank.org/products/wdi laccessed for the last time on July 29, 2016). 